\title{
THE \\ ENVIRONMENTAL \\ TURN IN POSTWAR \\ SWEDEN
}

A new history of knowledge

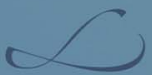

DAVID LARSSON HEIDENBLAD 


\section{THE ENVIRONMENTAL TURN IN POSTWAR SWEDEN}

A new history of knowledge 
David Larsson Heidenblad - 9789198557749 Downloaded from manchesterhive.com at 04/26/2023 02: 08 : $04 \mathrm{PM}$ 


\title{
The environmental turn in postwar Sweden
}

\author{
A new history of knowledge \\ DAVID LARSSON HEIDENBLAD
}

Translation: Arabella Childs

Lund University Press 
The right of David Larsson Heidenblad to be identified as the author of this work has been asserted by him in accordance with the Copyright, Designs and Patents Act 1988.

Lund University Press

The Joint Faculties of Humanities and Theology

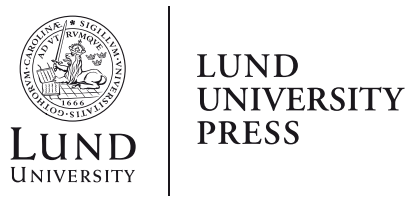

PO Box 191

SE-221 00 LUND

Sweden

http://lunduniversitypress.lu.se

Lund University Press books are published in collaboration with Manchester University Press.

British Library Cataloguing-in-Publication Data

A catalogue record for this book is available from the British Library

Lund University Press gratefully acknowledges publication assistance from the Thora Ohlsson Foundation (Thora Ohlssons stiftelse)

ISBN 978-91-985577-3-2 hardback

ISBN 978-91-985577-4-9 open access

First published 2021

This electronic version has been made available under a Creative Commons (CC-BY-NC-ND) licence, thanks to the support of Lund University, which permits non-commercial use, distribution and reproduction provided the author(s) and Lund University Press are fully cited and no modifications or adaptations are made. Details of the licence can be viewed at https://creativecommons.org/licenses/ by-nc-nd/4.0/

The publisher has no responsibility for the persistence or accuracy of URLs for any external or third-party internet websites referred to in this book, and does not guarantee that any content on such websites is, or will remain, accurate or appropriate.

Typeset by

Servis Filmsetting Ltd, Stockport, Cheshire 